\title{
Effects of different dietary manganese sources on thickness of mucus layer and selected biochemical and haematological indicators in sheep
}

\author{
Zuzana Maková ${ }^{1}$, Zita Faixová1 $^{1}$ Lucia Tarabová ${ }^{1}$, Elena Piešová1, Katarína Venglovská2, \\ Klaudia Čobanová2, L’ubomíra Grešáková2 ${ }^{2}$ Štefan Faix ${ }^{2}$ \\ ${ }^{1}$ University of Veterinary Medicine and Pharmacy in Košice, Institute of Pathological Physiology, \\ Košice, Slovak Republic \\ ${ }^{2}$ Slovak Academy of Sciences, Institute of Animal Physiology, Košice, Slovak Republic
}

Received June 1, 2017

Accepted December 7, 2018

\begin{abstract}
The effects of manganese from organic and inorganic sources supplemented to diets of sheep on intestinal mucus production and on selected biochemical and haematological indicators were investigated. The experiment was carried out on 18 sheep of the Improved Valachian breed aged seven months over the period of four months. The animals were divided into three groups of six animals each (group 1 - control, basal diet with $31 \mathrm{mg} \mathrm{Mn} / \mathrm{kg}$, group 2 - basal diet + manganese sulphate $\left(\mathrm{MnSO}_{4}\right)$ with $120 \mathrm{mg} \mathrm{Mn} / \mathrm{kg}$, group 3 - basal diet + manganese chelate of glycine hydrate (Mn-Gly) with $120 \mathrm{mg} \mathrm{Mn} / \mathrm{kg}$ ). Intestinal segments (duodenum, jejunum, ileum, caecum) were collected and mucus production was assessed using the quantification method. Mucus production in the duodenum and jejunum was significantly lower $(P<0.05)$ in group 3 (Mn-Gly) compared to the control and group $2\left(\mathrm{MnSO}_{4}\right)$. In the duodenum in group $2\left(\mathrm{MnSO}_{4}\right)$ mucus production was similar to the control. Biochemical indicators were determined using spectrophotometry, and haematological indicators were measured using a haematology analyzer. Significant changes $(P<0.05)$ were found for the concentrations of total proteins and albumins. The concentration of total proteins was lower in group 3 (Mn-Gly) compared to the control and group $2\left(\mathrm{MnSO}_{4}\right)$. In the latter group it was higher compared to the control. The concentration of albumins was higher in group 3 (Mn-Gly) compared to the control and group $2(P<0.05)$. The results indicate a decrease of intestinal mucus in the group supplemented by Mn-Gly chelate, which may mean a lower mucus barrier for manganese absorption.
\end{abstract}

Trace elements, bioavailability, ruminants

Manganese (Mn) is an essential trace element which plays a role in bone mineralization, blood clotting, and the reproductive and nervous systems. It is a part of the metalloenzymes that are involved in multiple physiological processes including respiration, carbohydrate, protein and lipid metabolism, as well as antioxidant protection (Andrieu 2008). Absorption and subsequent utilization of manganese in the body depend on the chemical form of $\mathrm{Mn}$ in the feed, but also on the quantity received (Š aric and Lucchini 2007). In livestock nutrition mainly inorganic forms of manganese are commonly used as additives. Absorption of inorganic forms of $\mathrm{Mn}$ is limited, however, mainly because of its tendency to form complexes with other components in the feed which are less useful or unavailable, and which interfere with each other in the digestive tract (Yan and Waldroup 2006). In recent years, therefore, organic sources have started to be used as well. Even though in commercial use, inorganic additives are still preferred over organic ones (Aksu et al. 2011). In the absorption of substances from the intestine the layer of mucus plays an important role as a protective barrier between luminal content and the absorbent system of the gastrointestinal tract.

Manganese has an antagonistic relationship with iron, and both elements can bind to transferrin (TfR) and divalent metal transporter 1 (DMT-1) receptors, which play a role

Address for correspondence:

Zuzana Maková

Institute of Pathological Physiology

University of Veterinary Medicine and Pharmacy in Košice

Komenského 73, 04181 Košice, Slovak Republic

Phone: +421915984711

E-mail: zuzana.makova@uvlf.sk

http://actavet.vfu.cz/ 
in the transport of manganese (Aschner and Aschner 2005). A reduced amount of iron makes it possible to bind more manganese to transferrin, and conversely. A diet with a high amount of manganese affects the iron absorption (Reeves et al. 2004) which can affect haematological indicators.

Considering the continued discussions on the use of inorganic or organic additives, the aim of our study was to compare the effect of manganese supplementation in sheep diet in two different forms (organic - Mn-Gly and inorganic - $\mathrm{MnSO}_{4}$ ) on the thickness of the mucus layer in segments of the intestines (duodenum, jejunum, ileum, caecum), and on selected biochemical and haematological indicators.

\section{Materials and Methods}

All procedures were in accordance with the European Community guidelines (Directive 2010/63/EU) for animal experiments, and the experimental protocol was approved by the Ethics Committee of the Institute of Animal Physiology SASci and by the State Veterinary and Food Office (Ro-1479/11-221/3).

Animal, diets, and experimental design

In the experiment seven-month-old sheep of the Improved Valachian breed were used. The animals were imported from an approved supplier PD Ol'šavica - Brutovce (farm registration number 403417), placed in an approved experimental facility (Physiological laboratories UFHZ, Košice, approval number SK U 07016), and divided into three groups of six animals each and kept on diets supplemented with different dietary forms of manganese for four months. The animals were housed in individual pens with fresh potable water ad libitum. The composition of basal diet consisted of $(\mathrm{g} / \mathrm{kg})$ : grass hay 800 , ground barley 300 , dry matter 895 , crude protein 101 , acid detergent fibre 206, neutral detergent fibre 320, ash 66, manganese $31.1 \mathrm{mg} / \mathrm{kg}$, zinc $30 \mathrm{mg} / \mathrm{kg}$, and copper $' 7.6 \mathrm{mg} / \mathrm{kg}$. The mineral lick (offered once a week without $\mathrm{Mn}$ ) consisted of (g/kg): $\mathrm{Ca} \mathrm{16.2,} \mathrm{Na} \mathrm{316,} \mathrm{Mg} \mathrm{32,}$ $\mathrm{Cu} 0.5, \mathrm{Zn} \mathrm{3.1,} \mathrm{Co} \mathrm{0.06,} \mathrm{I} \mathrm{0.02,} \mathrm{Se} \mathrm{0.01.} \mathrm{The} \mathrm{control} \mathrm{group} \mathrm{(group} \mathrm{1)} \mathrm{was} \mathrm{fed} \mathrm{the} \mathrm{unsupplemented} \mathrm{basal} \mathrm{diet} \mathrm{with}$ analysed $31 \mathrm{mg} \mathrm{Mn} / \mathrm{kg}$. Group 2 received the basal diet supplemented with $120 \mathrm{mg} \mathrm{Mn} / \mathrm{kg}$ of inorganic manganese in the form of manganese sulphate monohydrate $\left(\mathrm{MnSO}_{4} \cdot \mathrm{H}_{2} \mathrm{O}\right.$, Sigma-Aldrich, USA). Group 3 received the basal diet supplemented with $120 \mathrm{mg} \mathrm{Mn} / \mathrm{kg}$ of organic manganese in the form of manganese chelate of glycine hydrate (Glycinoplex-Mn 22\%, Phytobiotics, Futterzusatzstoffe GmbH, Etville, Germany). The supplemented diets were formulated to contain $150 \mathrm{mg} \mathrm{Mn} / \mathrm{kg}$ of diet (maximum total Mn content allowed in the European Union).

Biochemical and haematological indicators

Jugular blood samples were collected into heparinized test tubes and were used to determine biochemical and haematological indicators.

Biochemical indicators were determined by means of spectrophotometry using a Genesys 10 UV spectrophotometer analyser (Rochester, NY, USA) with commercial kits from Randox Laboratories Ltd., UK (potassium K, cholesterol CHOL, total protein TP 245, AST - aspartate aminotransferase AS 147, ALT - alanine aminotransferase AL 146, total bilirubin T Bil) and with kits from Erba Lachema s.r.o, Karásek 1d, CZ (phosphorus LYO P, calcium Ca L, magnesium Mg L, albumine ALBU L 500, glucose GLU GOD 250).

White blood cells (WBC), red blood cells (RBC), haemoglobin ( $\mathrm{Hb}$ ), mean corpuscular haemoglobin $(\mathrm{MCH})$, mean corpuscular volume (MCV) and platelets (PLT) were measured on an Abbott CELL-DYN 3700 System haematology analyzer.

Mucus quantification

After four months the animals were euthanized and each segment obtained from all parts of the intestine (duodenum, jejunum, ileum, caecum) was reversed, flushed with $0.15 \mathrm{M} \mathrm{NaCl}$, measured and used for mucus quantification by the method of Smirnov et al. (2004) and modified by Thompson and Applegate (2006). Each sample $(100 \mu 1$ in triplicate) was plated on a 96-well plate chamber and processed in an ELISA Absorbance Reader (LB 913 Apollo 11, Berthold Technologies, USA) at a wavelength of $630 \mathrm{~nm}$. A measured quantity of Alcian Blue $(\mathrm{AB})$ with bound mucus was calculated using a standard curve and expressed in $\mu \mathrm{gAB} / \mathrm{cm}^{2}$ of intestine.

Statistical analysis

Statistical analysis of results was performed using one-way analysis of variance (ANOVA) with Tukey's post hoc multiple comparison test (GraphPad Software, USA). The differences between the mean values of the different tratment groups were considered significant at $P<0.05$.

\section{Results}

The thickness of the mucus layer of the intestines (duodenum, jejunum, ileum, caecum) in sheep fed diets supplemented with different forms of manganese was measured. Significant 
changes occured in the duodenum and jejunum. The mucus layer in the duodenum was significantly lower $(P<0.05)$ in group 3 (Mn-Gly) compared to the control and group $2\left(\mathrm{MnSO}_{4}\right)$, and also in group $2\left(\mathrm{MnSO}_{4}\right)$ compared to the control. In the jejunum it was similar, but a significant decrease $(P<0.05)$ was found in group 3 (Mn-Gly) compared to the control and group $2\left(\mathrm{MnSO}_{4}\right)$. A measured quantity of Alcian Blue $(\mathrm{AB})$ with bound mucus, subsequently calculated using a standard curve and expressed in $\mu \mathrm{gAB} / \mathrm{cm}^{2}$ of intestine is reported in Table 1.

Table 1 Thickness of the mucus layer in different sections of the intestine in sheep fed diets enriched with different forms of manganese $\left(\mu \mathrm{g} \mathrm{AB} / \mathrm{cm}^{2}\right)$.

\begin{tabular}{lccc}
\hline & $\begin{array}{c}\text { Group 1 } \\
\text { Control }\end{array}$ & $\begin{array}{c}\text { Group 2 } \\
\mathrm{MnSO}_{4}\end{array}$ & $\begin{array}{c}\text { Group 3 } \\
\text { Mn-Gly }\end{array}$ \\
\hline Duodenum & $5.77 \pm 0.11^{\mathrm{ab}}$ & $5.10 \pm 0.16^{\mathrm{ac}}$ & $3.63 \pm 0.27^{\mathrm{bc}}$ \\
Jejunum & $4.09 \pm 0.19^{\mathrm{a}}$ & $3.85 \pm 0.11^{\mathrm{b}}$ & $3.08 \pm 0.23^{\mathrm{ab}}$ \\
Ileum & $2.98 \pm 0.13$ & $3.82 \pm 0.38$ & $3.76 \pm 0.23$ \\
Caecum & $3.21 \pm 0.10$ & $3.26 \pm 0.13$ & $3.18 \pm 0.15$ \\
\hline
\end{tabular}

Significant differences between groups are marked with the same superscript, $P<0.05 ; \mathrm{n}=6 ;$ mean $\pm \mathrm{SEM}-$ standard error of the mean; AB - Alcian Blue

The effects of organic (Mn-Gly) and inorganic $\left(\mathrm{MnSO}_{4}\right)$ forms of manganese on concentrations of phosphorus, potassium, calcium, magnesium, cholesterol, total proteins, albumine, AST, ALT, total bilirubin and glukose in the blood plasma of sheep were detected. In terms of biochemical indicators, significant changes were found in the concentrations of total proteins and albumins. The concentration of total proteins was lower $(P<0.05)$ in group 3 (Mn-Gly) compared to the control and group $2\left(\mathrm{MnSO}_{4}\right)$. In group $2\left(\mathrm{MnSO}_{4}\right)$ it was higher $(P<0.05)$ compared to the control. The concentration of albumins was higher $(P<0.05)$ in group 3 (Mn-Gly) compared to the control and group $2\left(\mathrm{MnSO}_{4}\right)$. Measured concentrations of selected biochemical indicators are reported in Table 2.

Table 2. Effects of organic and inorganic forms of manganese on biochemical indicators.

\begin{tabular}{lccc}
\hline Indicator & $\begin{array}{c}\text { Group 1 } \\
\text { Control }\end{array}$ & $\begin{array}{c}\text { Group 2 } \\
\text { MnSO }_{4}\end{array}$ & $\begin{array}{c}\text { Group 3 } \\
\text { Mn-Gly }\end{array}$ \\
\hline Phosphorus $\left(\mathrm{mmol} \cdot \mathrm{l}^{-1}\right)$ & $1.88 \pm 0.03$ & $1.76 \pm 0.15$ & $1.87 \pm 0.23$ \\
Potassium $\left(\mathrm{mmol} \cdot \mathrm{l}^{-1}\right)$ & $3.14 \pm 0.53$ & $3.61 \pm 0.41$ & $3.41 \pm 0.34$ \\
Calcium $\left(\mathrm{mmol} \cdot \mathrm{l}^{-1}\right)$ & $2.69 \pm 0.17$ & $3.19 \pm 0.08$ & $2.90 \pm 0.30$ \\
Magnesium $\left(\mathrm{mmol} \cdot 1^{-1}\right)$ & $0.79 \pm 0.07$ & $0.79 \pm 0.04$ & $0.84 \pm 0.03$ \\
Cholesterol $\left(\mathrm{mmol} \cdot \mathrm{l}^{-1}\right)$ & $1.54 \pm 0.19$ & $1.55 \pm 0.11$ & $1.60 \pm 0.13$ \\
Total proteins $\left(\mathrm{g} \cdot \mathrm{l}^{-1}\right)$ & $65.51 \pm 1.91^{\mathrm{ab}}$ & $74.20 \pm 3.32^{\mathrm{ac}}$ & $58.11 \pm 1.882^{\mathrm{bc}}$ \\
Albumine $\left(\mathrm{g} \cdot \mathrm{l}^{-1}\right)$ & $27.20 \pm 1.16^{\mathrm{a}}$ & $33.20 \pm 2.52^{\mathrm{b}}$ & $35.20 \pm 1.29^{\mathrm{ab}}$ \\
AST $\left(\mu \mathrm{kat} \cdot \mathrm{l}^{-1}\right)$ & $1.38 \pm 0.06$ & $1.40 \pm 0.08$ & $1.67 \pm 0.14$ \\
ALT $\left(\mu \mathrm{kat} \cdot \mathrm{l}^{-1}\right)$ & $0.52 \pm 0.08$ & $0.41 \pm 0.08$ & $0.50 \pm 0.02$ \\
Total bilirubin $\left(\mathrm{mmol} \cdot \mathrm{l}^{-1}\right)$ & $3.74 \pm 0.49$ & $4.33 \pm 0.37$ & $3.65 \pm 0.44$ \\
Glukose $\left(\mathrm{mmol} \cdot \mathrm{l}^{-1}\right)$ & $1.53 \pm 0.15$ & $2.11 \pm 0.32$ & $2.53 \pm 0.41$ \\
\hline
\end{tabular}

AST - aspartate aminotransferase; ALT - alanine aminotransferase; significant differences between groups are marked with the same superscript, $P<0.05 ; \mathrm{n}=6$; mean $\pm \mathrm{SEM}-$ standard error of the mean

The effect of manganese supplemented to the sheep diet in the different forms of Mn-Gly chelate and $\mathrm{MnSO}_{4}$ on the $\mathrm{WBC}, \mathrm{RBC}, \mathrm{Hb}, \mathrm{MCH}, \mathrm{MCV}$, and PLT was detected. There 
Table 3. Effects of organic and inorganic forms of manganese on haematological indicators.

\begin{tabular}{lccr}
\hline Indicator & $\begin{array}{c}\text { Group 1 } \\
\text { Control }\end{array}$ & $\begin{array}{c}\text { Group 2 } \\
\text { MnSO }_{4}\end{array}$ & $\begin{array}{c}\text { Group 3 } \\
\text { Mn-Gly }\end{array}$ \\
\hline $\mathrm{WBC}\left(\mathrm{G} \cdot \mathrm{l}^{-1}\right)$ & $8.66 \pm 0.81$ & $9.71 \pm 1.03$ & $8.63 \pm 0.93$ \\
$\mathrm{RBC}\left(\mathrm{T} \cdot \mathrm{l}^{-1}\right)$ & $9.52 \pm 0.19$ & $9.71 \pm 0.35$ & $9.83 \pm 0.30$ \\
$\mathrm{Hb}\left(\mathrm{g} \cdot \mathrm{l}^{-1}\right)$ & $122.70 \pm 4.10$ & $127.0 \pm 3.81$ & $126.50 \pm 4.06$ \\
$\mathrm{MCH}(\mathrm{pg})$ & $12.83 \pm 0.21$ & $12.12 \pm 0.29$ & $12.87 \pm 0.19$ \\
$\mathrm{MCV}(\mathrm{fl})$ & $24.18 \pm 0.42$ & $23.93 \pm 0.39$ & $24.25 \pm 0.41$ \\
$\mathrm{PLT}\left(\mathrm{G} \cdot \mathrm{l}^{-1}\right)$ & $400.30 \pm 63.20$ & $479.80 \pm 99.40$ & $506.0 \pm 60.50$ \\
\hline
\end{tabular}

Significant differences between groups are marked with the same superscript, $P<0.05 ; \mathrm{n}=6 ;$ mean $\pm \mathrm{SEM}-$ standard error of the mean

were no diferences in haematological indicators between groups. Observed values are reported in Table 3.

\section{Discussion}

The capacity for absorption of manganese across the digestive system depends on several factors. These include the received quantity of manganese, the chemical form of manganese in the feed, interactions with other components in the diet, intestinal $\mathrm{pH}$, animal species (ruminants absorb about $1 \%$ of received manganese), age (younger animals absorb better than older), and the physiological status of the animal (Männer and Bronsch 1987). The benefit to the feeding of organic trace minerals is that they should undergo less dissociation in the reticulo-rumen, omasum, and abomasum than their inorganic counterparts. Organic trace minerals which remain intact in the upper gastro-intestinal tract are less likely to form insoluble and indigestible compounds than inorganic trace minerals, and thus the availability of organic trace minerals for absorption by intestinal tissues should be enhanced. An ideal organic trace mineral supplement must be resilient enough to remain intact as the $\mathrm{pH}$ changes throughout the digestive tract, but must still be available for absorption and metabolism by animal tissues (Andrieu 2008; Spears 2003). In reality, this ideal organic trace mineral does not exist. In vitro studies have shown that organic trace minerals are more effectively absorbed by gut tissues than inorganic trace minerals (Predieri et al. 2005; Wright et al. 2008). However, some extent of dissociation and loss of organic trace minerals in the upper gastro-intestinal tract is unavoidable (Ca o et al. 2000). Despite these inevitable losses, organic trace mineral supplementation can benefit the nutrition of ruminants, improving their production and health (Gressley 2009; Dresler et al. 2016).

A very important role in the absorption of substances in the intestine is played by a mucus that consists mainly of mucin glycoproteins which are synthesized by goblet cells dispersed between the enterocytes. The mucus forms a barrier between the epithelium and the lumen, and its role is to enable the transport of nutrients and to prevent the penetration of undesirable molecules into enterocytes. Mucus secretion is induced by various stimuli. Excessive secretion increases endogenous nutritional losses and impacts absorption of nutrients (Caspary 1992).

According to our results, the most pronounced decrease in the mucus layer was in the third group (Mn-Gly), in the duodenum and jejunum. We assume that this decline could lead to a smaller mucus barrier, and thus better absorbtion of manganese in the intestine. We can only speculate that the decline of the mucus layer after supplementation by MnGly chelate is due to this special organic form being absorbed in an intact form, belonging to stable, electrically neutral complexes that protect trace minerals from chemical reactions during digestion. In the case of an inorganic form, interactions with mucus formation are 
considered, which is manifested by its increased secretion. The mucus layer acts as a filter in regulating metal uptake and the strength of binding to and rate of passage across the mucosally-adherent mucus layer could be important in determining the overall absorption of a metal (Powell et al. 1999; Power and Horgan 2007). In addition to the organic form which undergoes less dissociation in the forestomach than the inorganic form, other factors that might play a positive role are young age and the good physiological condition of animals.

Manganese after absorption in the blood forms a complex with the plasma proteins albumin and $\alpha 2$-macroglobulin, and is transported by the portal circulation into the liver (NRC 2005). In our results the concentration of albumins reached significantly higher levels in the group 3 (Mn-Gly) compared to the control and group $2\left(\mathrm{MnSO}_{4}\right)$. The cause of the higher concentration of albumins in the group supplemented by Mn-Gly chelate is questionable. We can only speculate about the relationship between higher absorption of manganese and a higher concentration of albumin, or their synthesis in the liver. Manganese after absorption in the blood forms a complex with plasma proteins, in particular with albumin, and it is transported by portal circulation to the liver (NRC 2005). We can assume that the higher concentration of albumins, after supplementation with an organic form of manganese, is associated with higher manganese absorption from the intestine into the blood, indicating increased stability of the organic mineral supplement in the digestive tract and thus better bioavailability of manganese for the organism. Plasma proteins are removed in the liver, and the liberated manganese can be further oxidized (Andersen et al. 1999). Manganese leaves the liver together with the iron bound to transferrin and the DMT1 transporter (Au et al. 2008; De Domenico et al. 2008), by means of which they are transported to the peripheral tissues. Although manganese is in an antagonistic relationship with iron, more manganese can limit iron transport. Iron deficiency can manifest altered haematological indicators which are characteristic of anaemia, but this was not confirmed in our results. Most likely it would be possible with higher doses of manganese, bordering on toxicosis (Indravathi et al. 2014; Sharma and Langer 2014). Although manganese is considered to be the least toxic trace mineral element per os (NRC 2005), a certain risk is inherent precisely in the introduction of new organic and inorganic forms into animal feed (Miles et al. 2003).

In conclusion, our results help to describe the ability of intestinal absorption of manganese after its supplementation in various forms to the sheep diet. Organic mineral supplements, which are more stable in the digestive tract in ruminants and therefore more accessible to the intestinal absorption, have a greater potential to be more suitable for the animal metabolism than inorganic mineral supplements. However, it is necessary to continue with further experiments and to extend them to include indicators that will help to explore alternative explanations of absorption mechanisms and subsequent bioavailability of substances.

\section{Acknowledgment}

This study was supported by the Grant Agency for Science (VEGA) of the Slovak Republic, grants No. 1/0374/14, No. 2/0009/14, No. 1/0658/17 and by the Research and Development Support Agency (APVV) of the Slovak Republic, grant No. 0667-12.

\section{References}

Aksu T, Aksu MI, Yoruk MA, Karaoglu M 2011: Effects of organically-complexed minerals on meat quality in chickens. Br Poult Sci 52: 558-563

Andersen ME, Gearhart JM, Clewell HJ 1999: Pharmacokinetic data needs to support risk assessments for inhaled and ingested manganese. Neurotoxicology 20: 161-171

Andrieu $\boldsymbol{S}$ 2008: Is there a role for organic trace element supplements in transition cow health? Vet J 176: 77-83

Aschner JL, Aschner M 2005: Nutritional aspects of manganese homeostasis. Mol Aspects Med 26: 353-362

$\mathrm{Au}$ C, Benedetto A, Aschner M 2008: Manganese transport in eukaryotes: the role of DMT1. Neurotoxicology 29: $569-576$ 
Cao J, Henry PR, Guo R, Holwerda RA, Toth JP, Littell RC, Miles RD, Ammerman CB 2000: Chemical characteristics and relative bioavailability of supplemental organic zinc sources for poultry and ruminants. J Anim Sci 78: 2039-2054

Caspary WT 1992: Physiology and pathophysiology of intestinal absorption. Am J Clin Nutr 55: 299-308

De Domenico I, McVey Ward D, Kaplan J 2008: Regulation of iron acquisition and storage: consequences for iron-linked disorders. Nat Rev Mol Cell Biol 9: 72-81

Dresler S, Illek J, Zeman L 2016: Effects of organic zinc supplementation in weaned calves. Acta Vet Brno 85 : 49-54

Gressley FT 2009: Zinc, copper, manganese and selenium in dairy cattle rations. Proceedings of the $7^{\text {th }}$ Annual Mid-Atlantic Nutrition Conference, pp. 65-71

Indravathi G, Kiran Kumari K, Bhuvaneswari Devi C 2014: Manganese induced haematological alterations in albino rats: reversal effect of alpha-tocopherol. Int J Innov Res Sci Eng Tech 3: 14988-17999

Männer MK, Bronsch K 1987: Mineralstoffe. Lehrbuch der Veterinär-Physiology, Berlin and Hamburg, pp. 112-113

Miles RD, Henry PR, Sampath VC, Shivazad M, Corner CW 2003: Relative bioavailability of novel chelates of manganese and copper for chicks. J Appl Poultry Res 12: 417-423

NRC 2005: Subcommittee on spacecraft exposure guidelines. Spacecraft water exposure guidelines for selected contaminants 2: 364

Powell JD, Whitehead MW, Ainley CC, Kendall MD, Nicholson JK, Thompson RPH 1999: Dietary minerals in the gastrointestinal tract: hydroxypolymerisation of aluminium in regulated by luminal mucins. J Inorg Biochem 75: 167-180.

Power R, Horgan K 2007: Biological chemistry and absorption of inorganic and organic trace metals. European Bioscience Centre, Alltech Inc, Dunboyne, Co Meath, Ireland

Predieri G, Elviri L, Tegoni M, Zagnoni I, Cinti E, Biagi G, Ferruzza S, Leonardi G 2005: Metal chelates of 2-hydroxy-4-methylthiobutanoic acid in animal feeding. Part 2: Further characterizations, in vitro and in vivo investigations. J Inorg Biochem 99: 627-636

Reeves PG, Ralston NVC, Idso JP, Lukaski HC 2004: Contrasting and cooperative effects of copper and iron deficiencies in male rats fed different concentrations of manganese and different sources of sulfur amino acids in an AIN-93G-based diet. J Nutr 134: 416-425

Sharma J, Langer S 2014: Effect of manganese on haematological parameters of fish Garra gotyla gotyla. J Entomol Zool Stud 2: 77-81

Smirnov A, Sklan D, Uni Z 2004: Mucin dynamics in the chick small intestine are alterated by starvation. J Nutr 134: $736-742$

Spears JW 2003: Trace mineral bioavailability in ruminants. J Nutr 133: 1506-1509

Šric M, Lucchini R 2007: Manganese. Handbook on the Toxicology of Metals. Academic Press Inc, Burlington, pp. 645-674

Thompson KL, Applegate TJ 2006: Feed withdrawal alters small-intestinal morphology and mucus of broilers. Poult Sci 85: 1535-1540

Wright CL, Spears JW, Webb KE Jr 2008: Uptake of zinc from zinc sulfate and zinc proteinate by ovine ruminal and omasal epithelia. J Anim Sci 86: 1357-1363

Yan F, Waldroup PW 2006: Evaluation of mintrex manganese as a source of manganese for young broilers. Int J Poult Sci 5: 708-713 